\title{
Kohti valveutumista ja ajattelun rajoja kriittisen pedagogiikan keinoilla
}

\author{
Aleksi Fornaciari ja Tiina Nikkola
}

\section{TIIVISTELMÄ}

Katsauksessa pohdimme kriittisen pedagogiikan mahdollisuuksia lisätä opettajaopiskelijoiden kykyä jäsentää yhteiskunnallisten ilmiöiden suhdetta kasvatukseen. Esimerkkinä käytämme Lapset elämänsä valtiaiksi -hanketta, jota Tampereen ammattikorkeakoulun sosionomikoulutuksessa on toteutettu Venäjällä ja Virossa. Siinä sosiokulttuurisen innostamisen avulla, opiskelijoiden oman osallistumisen kautta, pyritään luomaan solidaarisuuteen ja tasa-arvoon kurkottavia yksilöitä. Toiminnan keskeisiä arvoja ovat yhteisöllisyys, osallistuminen, dialogi ja luovuus. Prosessin päämääränä on todellisuuden kriittinen tarkastelu ja siitä kumpuava toiminta. Kriittisen pedagogiikan sovelluksia toteutetaan yliopistokentällä kauttaaltaan suhteellisen vähän. Varsinkin opettajankoulutuksen ja kasvatustieteen kentällä koulun ulkopuolelle suuntautuva yhteiskunnallinen ja kriittinen toiminta on harvinaista. Myös yhteiskunnallista tiedostamista lisäävät lähestymistavat, kuten demokratia- ja osallisuuskasvatus tai kriittisen ajattelun taidot, ovat vähäisessä roolissa niin peruskouluissa kuin opettajankoulutuksessakin. Esittelemme Lapset elämänsä valtiaiksi -hankkeen pitkäaikaisen projektikoordinaattorin kanssa käydyn keskustelun pohjalta hankkeen toimintaa sekä pohdimme taustalla vaikuttavan freireläisen kriittisen pedagogiikan ja sen tavoitteiden pedagogista ja tutkimuksellista antia myös opettajankoulutukselle. Kriittisen pedagogiikan keinoin on mahdollista syventää opettajaopiskelijoiden yhteiskunnallista ajattelua sekä terävöittää ymmärrystä kokemuksen, reflektion ja toiminnan yhteydestä.

Asiasanat: kriittinen pedagogiikka, opettajankoulutus, sosiokulttuurinen innostaminen, kriittinen reflektio 


\section{ABSTRACT \\ TOWARDS AWARENESS AND THE LIMITS OF THINKING WITH CRITICAL PEDAGOGY.}

In this review, we reflect the use of transformative study methods in the Finnish teacher education. In particular, we argue that transformative studying might increase student teachers societal understanding. As an example of transformative implementation in university field, we present the "Lapset elämänsä valtiaiksi" -project undertaken in the University of Applied sciences of Tampere. In this project, the target is to observe societal environment and to create critical thinking and reflection amongst the students participating in the action.

In the university field, transformative pedagogy is a relatively rarely used study method. Especially in teacher education, activities outside the school environment are rare. Furthermore, throughout teacher training curricula, societal topics like democracy and citizenship education, have a minor emphasis. Via conversation held with the long-period project manager of the "Lapset elämänsä valtiaiksi" -project, in this review we demonstrate the philosophical and pedagogical objectives of the project. We suggest that these objectives should be emphasized more also in the teacher training.

Keywords: transformative teacher thinking, teacher education, critical awareness

\section{Johdanto}

$S_{\text {mo }}^{y}$ yksyllä 2016 käyttöön tullut opetussuunnitelmauudistus painottaa, monien muiden tavoitteiden ohella, entistä voimakkaammin oppilaiden kasvattamista demokraattisiksi, autonomisiksi ja yhteiskunnan kanssa vuoropuheleviksi toimijoiksi (POPS 2014, 14). Koska yhteiskunnallinen ulottuvuus on suomalaisessa koulussa ja opettajuudessa muotoutunut näennäisen neutraaliksi ja jopa passiiviseksi, asettaa tämä haasteita nykyopettajien toiminnalle (ks. esim. Fornaciari \& Männistö 2017; Räisänen 2014; Vuorikoski \& Räisänen 2010; Säntti 2007; Linden 2010). Suomalaisessa opettajankoulutuksessa ei myöskään ole pidetty keskeisenä tehtävänä kouluttaa kriittisyyteen ja yhteiskunnalliseen aktiivisuuteen tähtääviä opettajia (Rautiainen, Vanhanen-Nuutinen \& Virta 2014, 85-86; Männistö, Fornaciari \& Tervasmäki 2017). Nykyisellään yhteiskunnallista tiedostamista lisäävät lähestymistavat ja näkökulmat opettajan ammattiin ja koulumaailmaan, kuten demokratia- ja osallisuuskasvatus tai kriittisen ajattelun taidot, ovat vähäisessä roolissa niin peruskoulussa kuin opettajan- 
koulutuksessakin (ks. esim. Simola, Kauko, Varjo, Kalalahti \& Sahlström 2017). Jotta opettajien yhteiskunnallinen valveutuminen kehittyisi, nykyisen opettajankoulutuksen didaktis-psykologisen painotuksen tulisi antaa vielä nykyistä enemmän tilaa yhteiskunnallisten ilmiöiden tarkastelulle (ks. esim. Husu \& Toom 2016; Syrjäläinen, Eronen \& Värri 2006).

Tässä katsauksessa pohdimme käytännön esimerkin kautta toivon pedagogiikan kasvatuksellisia päämääriä ja niiden potentiaalia lisätä opettajaopiskelijoiden kykyä jäsentää yhteiskunnallisia ilmiöitä kasvatuksessa. Esimerkkinä käytämme Lapset elämänsä valtiaiksi -hanketta, jota on Tampereen ammattikorkeakoulun sosionomikoulutuksessa toteutettu Venäjällä ja Virossa. Toivon pedagogiikka on kriittisen pedagogiikan katsanto, joka perustuu ennen muuta ajatukseen siitä, että oppimisen ja opettamisen yksi keskeinen päämäärä on maailman muuttaminen paremmaksi (Giroux \& Mclaren 2001; Freire 2018). Tavoitteena on ihmisten henkilökohtaisen osallistumisen avulla luoda solidaarisuuteen ja tasa-arvoon tähtääviä yksilöitä. Toivon pedagogiikan keskeisiä periaatteita ovat yhteisöllisyys, osallistuminen, dialogi ja luovuus. Näistä johdettujen prosessien päämäärä on asioiden kriittinen ja syvällinen tarkastelu sekä siitä viriävät toimenpiteet (mm. Freire 2018).

Toivon pedagogiikkaa toteutetaan korkeakoulukentällä kauttaaltaan suhteellisen vähän. Vaikka kriittisellä pedagogiikalla on kasvatustieteessä jalansijansa, on koulun ulkopuolelle suuntautuva yhteiskunnallinen ja kriittinen todellisuuden tutkailu harvinaista (ks. kuitenkin esim. Suojanen 2014). Eniten kriittisen pedagogiikan toimintatapoja ja teoriaa on Suomessa ylläpitänyt ja kehittänyt kasvatustieteilijä Juha Suoranta tutkijakollegoineen (esim. Suoranta \& Ryynänen 2014; myös Syrjäläinen ym. 2006; Kiilakoski, Kinnunen \& Djupsund 2015; Nikkola, Rautiainen \& Räihä 2013). Esittelemme Lapset elämänsä valtiaiksi -hankkeen pitkäaikaisen projektikoordinaattorin kanssa käydyn keskustelun innoittamana hankkeen toimintaa ja jäsennämme sen kriittisen pedagogiikan perinteeseen kytkeytyvää kasvatuksellista ja tutkimuksellista antia opettajankoulutukselle.

\section{Lapset elämänsä valtiaiksi -hanke}

Tampereen ammattikorkeakoulun sosionomikoulutuksen (silloinen PIRAMK) toteuttama yhteistyöprojekti Venäjälle ja Viroon sai alkunsa 1990-luvulla Neuvostoliiton hajottua, jolloin monet suomalaisyhdistykset alkoivat harjoittaa humanitaarista toimintaa entisen Neuvostoliiton epävakailla alueilla, kuten Itä-Virossa (Salomäki 2010). Koska PIRAMK:in 
sosiaalialan (nykyinen TAMK:in sosiaaliala) taustayhteisönä toimivalla Mannerheimin Lastensuojeluliitolla oli hyvät suhteet eri puolille Viroa, vastasi haasteita pelkäämätön kolmen opettajan ja kolmen opiskelijan joukko myöntävästi kutsuun lähteä mukaan suunnittelemaan turvataloa Viron Tarttoon. MLL:n ja sosiaalialan oppilaitoksen ryhmän yhteistyö käynnistyi filantrooppisena avunantona, johon osallistui myös muutama suomalainen yhdistys toimittaen kenkiä, vaatteita ja leluja turvataloihin. Tarton turvatalossa, jossa lapset elivät jatkuvan puutteen ja köyhyyden keskellä, päätti lehtori Salomäki ryhmänsä kanssa ryhtyä konkreettiseen työhön toimintaolosuhteiden kohentamiseksi. Näin alkoi sittemmin teemoitettujen projektimatkojen ja yhteistoiminnan 20 -vuotinen taival, joka on laajentunut Venäjälle ja muualle Viroon. Nykyisin Tampereen ammattikorkeakoulu järjestää opiskelijoilleen 2-3 kertaa vuodessa noin viikon mittaisen opintomatkan yhteistyökohteisiin.

Vuosien kuluessa toiminta on konkreettisen auttamisen ohella muuttunut paikallisten lasten ja ammattilaisten kanssa yhdessä suunniteltavaksi ja organisoitavaksi pedagogiseksi toiminnaksi. Lapset elämänsä valtiaiksi -nimellä kulkeva hanke on osa sosionomitutkinnon sosiaalipedagogiikan opintoja ja nimensä mukaisesti pyrkii auttamaan konkreettisesti apua tarvitsevia lapsia ja nuoria sekä vahvistamaan riskiolosuhteissa elävien lasten ääntä ja näkyvyyttä muualla yhteiskunnassa. Toiminnan tavoitteena on auttaa lasten ja nuorten kasvua täysivaltaisiksi yhteiskunnan jäseniksi esimerkiksi kulttuurisen demokratian (valokuvaus, video ym.) keinoin. Kohteina toimivissa turvataloissa ja sijaiskodeissa tavataan esimerkiksi sotaa ja väkivaltaa pakenevia lapsia sekä ihmiskaupan ja seksuaalisen hyväksikäytön uhreja. Nykyisin yhteistyötä paikan päällä tehdään myös Pietarissa sijaitsevan Herzenin yliopiston sosiaalipedagogisen yksikön kanssa. 2000-luvulla on järjestetty seminaareja päihteisiin, lähisuhdeväkivaltaan ja koulukiusaamiseen liittyen.

Kokonaisuudessaan hanke koostuu useammasta eri vuosina aloitetusta ja siten päällekkäisestäkin osaprojektista. Sellaisia ovat olleet esimerkiksi Koulu on siistiä! -projekti, jossa pyrittiin tukemaan lasten positiivisia koulukokemuksia ja saamaan nuoria, joiden koulutie oli syystä tai toisesta katkennut, palaamaan takaisin kouluun. Osana hanketta on järjestetty myös monikansallinen Minors in sex trade -projekti (mukana mm. Opetus- ja kulttuuriministeriö, Keskusrikospoliisi, Sosiaali- ja terveysalan tutkimus- ja kehittämiskeskus, Helsingin ja Pietarin poliisit sekä useita kansalaisjärjestöjä), jossa tehtävänä oli kartoittaa eri turvatalojen kautta sek- 
suaalista hyväksikäyttöä Pietarissa. Vuonna 2009 valmistettiin pietarilaisen turvakodin lasten tekemä video Turvakoti Prijutin (Turvakotimme). Video oli esillä Tampereen kansainvälisillä filmifestivaaleilla sekä Helsingissä Minun elokuvani -tapahtumassa. Mukaan on vuosien varrella mahtunut myös esimerkiksi saunan rakentamista Tarttoon ja valokuvanäyttelyn järjestämistä Viipurissa.

\section{Valveutumista ja dialogia}

Vuosittain Tampereen ammattikorkeakoulun lehtori Tapio Salomäki johtaa monenkirjavan opiskelijaryhmän viikon mittaiselle projektimatkalle Venäjälle, Viipurin ja Pietariin. Salomäki on koordinoinut projektia koko sen elinkaaren ajan. Salomäen mukaan on aina ryhmäkohtaista, mitä milloinkin tapahtuu. Vuosien saatossa toiminta on kehittynyt kontingentisti - ei täysin suunnitellusti eikä sattumanvaraisesti, vaan risteytyvien pyrkimysten ja rakenteiden tuloksena - ja oman logiikkansa kautta. Nykyään toteutettavassa projektissa on myös tieteellisempiä sisältöjä, jotka toteutetaan yhteistyössä Herzenin yliopiston pedagogisen yksikön kanssa.

Salomäen mukaan venäläinen yhteiskunta tarjoaa oivan alustan itsestäänselvyyksien kyseenalaistamiselle. Kohdepaikkojen, kuten turvakotien, todellisuus ei päästä kohtaajaansa helpolla. Salomäen kokemuksen mukaan konkreettinen hyppy toisenlaiseen arkeen ja todellisuuteen avaa ajattelua usein luentosalia paremmin. Venäläinen yhteiskunta haastaa asenteita kautta linjan. Ihmetystä opiskelijoissa on herättänyt jo se, että Venäjän rajojen sisällä liikkuu useita erilaisia etnis-kulttuurisia pakolaisryhmiä, kuten ignuuseja, tataareja, kazakkeja tai azereja. "Kuka sinne nyt haluaa?" kuulee Salomäki usein kysyttävän. Opiskelijoiden keskuudessa varsinaisten teemojen ohella kysymyksiä herää sieltä täältä, kehnojen matkustusolosuhteiden ihmettelystä erilaiseen ruokakulttuuriin.

Projektin hyödyllisyyttä opintojen näkökulmasta Salomäki perustelee kauttaaltaan monipuolisesti. Laaja tavoite on, että opiskelijat astuisivat pois mukavuusalueeltaan sekä kohtaisivat tilanteita ja kohtaloita, joita muu yhteiskunta ei aina halua nähdä. Kokemukseen olennaisesti liittyvät ristiriitaiset ja epämukavatkin havainnot maailmasta saavat Salomäen mukaan aikaan syventymistä, jota ilman tiivistä läsnäolon kokemusta on hankala tavoittaa. Tuntemattomalle alueelle astumisen sekä epävarmuuden ja erilaisuuden kohtaamisen tavoitteena on virittää kokonaisvaltaista pohdintaa yhteiskunnastamme, sen toimintamekanismeista ja piirteistä. Ristiriitainen kokemus venäläisestä yhteiskuntatodellisuudesta se- 
kä omien ennakkoluulojen kyseenalaistaminen ovat Salomäen mukaan myös empatiakyvyn ja erilaisuuden sietokyvyn kehittymisen kannalta olennaisia kokemuksia.

Salomäki ei kiellä, etteikö Suomessa voisi toteuttaa samankaltaista hanketta, mutta katsoo, että venäläinen yhteiskunta tarjoaa herättelevämmän kokemuksen. Siellä myös yhteiskunnalliset ongelmat ovat hänen mukaansa pinnalla tai "näkyvillä" ja siksi helpommin käsiteltävissä. Yhteiskunnan varjopuolien kohtaaminen onkin hänen mukaansa ollut opiskelijoille todella merkityksellistä. Omastamme poikkeavan yhteiskunnallisen todellisuuden kohtaaminen on mahdollista maantieteellisesti lyhyen matkan päässä. Näin ollen Salomäen projektissa on siis kahtalainen tavoite. Yhtäältä on pyrkimys auttaa ja saada aikaan muutoksia venäläisessä yhteiskunnassa heikossa asemassa elävien ihmisten ja lasten elinolosuhteissa. Toinen tavoite on istuttaa opiskelijoiden katsantoon kriittisen ajattelun siemen, joka syntyy sosiaalisen todellisuuden erilaisten rakenteiden ja käytäntöjen tiedostamisesta ja epäkohtiin tarttumisesta.

\section{Kohti vierautta ja ammatillisen ajattelun rajoja}

Lapset elämänsä valtiaiksi -hankkeen ainoa tai edes tärkein anti opiskelijoille ei ole tutustuminen venäläiseen yhteiskuntaan tai ravistelevat kokemukset siitä. Olennaisimmaksi nousee dialektisemman maailmantulkinnan mahdollisuus, jota hankkeen kautta voi herätellä opiskelijoissa. Keskiössä ovat vuorovaikutus ja dialogisuus, joissa opiskelijat oppivat ymmärtämään eri näkökulmia sekä kyseenalaistamaan ja tarpeen tullen muuttamaan omia mielipiteitään ja suhtautumistaan. Kokemusten reflektointiin keskittyvien keskustelujen kautta opiskelijoita ohjataan ymmärtämään globaalia todellisuutta, yhteiskunnan kerrostumia sekä sosiaalisten epäkohtien luonnetta. Tällaiset tavoitteet tuntuisivat osuvilta ja tarpeellisilta myös opettajaksi opiskeleville, etenkin, kun aihealueen on jatkuvasti todettu olevan opettajankoulutuksessa heikosti edustettuna. Nykytutkimuksen valossa opettajankoulutuksen kykyä lisätä opettajien yhteiskunnallista valveutuneisuutta on kyseenalaistettu ja koulutuksen ongelmakohdiksi katsotaan vastaamattomuus nykykoulun vaatimuksiin sekä yhteiskunnallisen relevanssin vähyys (Simola ym. 2017; Fornaciari \& Männistö 2017; Fornaciari \& Harni 2017; Löfström, Virta \& Salo 2017). Opettajaopiskelijoiden on puolestaan usein todettu olevan keskimäärin neutraaleja, hieman konservatiivisia sekä yhteiskunnallisesti passiivisia ja taustaltaan keskiluokkaisia (ks. esim. Räihä 2010; Vuorikoski \& Räisänen 2010). 
Ajan saatossa opettajankoulutuslaitoksilla on ollut erilaisia pyrkimyksiä kehittää opetustaan vastaamaan nykyhetken ja tulevaisuuden haasteita. Vaikka opettajankoulutus on kauttaaltaan liikkunut pois teknis-rationaalisesta opetustaitojen opettelusta ja luokkahuoneen hallintataitojen hiomisesta kohti persoonan kehittämistä (ks. esim. Nikkola ym. 2013; Jokikokko 2005), silti kriittinen ja yhteiskunnallisesti painottunut opettajuus on yhä vaikeasti hahmotettava asia (esim. Sitomaniemi-San 2015). Usein kriittiset interventiot ja tutkimus saatetaan mieltää luokkahuonedidaktiseksi toiminnaksi eikä niinkään opettajan oman ymmärryksen ja ajattelun kehittämiseen liittyväksi projektiksi (esim. Sitomaniemi-San 2015; Salminen \& Säntti 2013).

Lapset elämänsä valtiaiksi -hankkeen sisällöt - osallistuminen yhteiskunnallisten asiantilojen havainnointiin ja niiden muuttamiseen - tuntuvat varsin tarpeellisilta myös opettajaopiskelijoille. Pedagogiset tavoitteet, kuten yhteiskunnallinen valveutuminen ja erilaisuuden ymmärtäminen, olisivat relevantteja tavoitteita myös opettajaksi kouluttautuville (ks. myös Salminen \& Säntti 2013; Värri 2004). Lapset elämänsä valtiaiksi -hankkeen toiminta ohjaa opiskelijoita kiinnostumaan yhteiskunnasta ja tarjoaa kriittistä ajattelua laukaisevia ristiriitaisia havaintoja maailmasta. Toisenlaiseen todellisuuteen astuminen ja erilaisuuden kohtaaminen virittää ajatuksia ennen muuta omista asenteista ja suhteesta ympäristöön. Tämä tarkoittaa, että yhteiskunnalliseen todellisuuteen tutustuessa herää väistämättä myös uudenlaisia henkilökohtaisia pohdintoja, jotka ovat kiinnittyneet yhteiskunnallisiin reunaehtoihin. Tämä johtaa niin konkreettisesti kuin teoreettisestikin kysymykseen sisäisen kokemuksen ja ulkoisten rakenteellisten ehtojen yhdistämisestä. Yksilön kokemusten ja rakenteellisen ymmärryksen suhdetta on toistaiseksi hyödynnetty vain vähän niin koulutuksessa kuin tutkimuksessakin. (Ks. Harni, Nikkola \& Saari 2018; Lapping 2011.) Ristiriitainen ja jopa karu kokemus saattaisi kirvoittaa opettajaopiskelijoita pohdintoihin, joita keskiverto opettajaopiskelijan elämässä ei vielä ole tarvinnut pohtia. Opettajaopiskelijoiden homogeeninen tausta huomioiden on oletettavaa, että suurelle joukolle opiskelijoita voi olla haastavaa ymmärtää esimerkiksi heikommista sosioekonomisista ja kulttuurisista taustoista ponnistavia oppilaita, jos heillä itsellään ei ole omakohtaisia kokemuksia erilaisuudesta. Siksi vähimmilläänkin tällainen projekti lisäisi opettajaopiskelijoiden kykyä kohdata eri lähtökohdista tulevia lapsia ja nuoria tulevaisuuden ammatissaan.

Koska Lapset elämänsä valtiaiksi -hankkeessa venäläiseen yhteiskunta- 
todellisuuteen loikkaamisen tavoitteena on yhtäälä vahvistaa ongelmaoloissa elävien ihmisten ääntä sekä toisaalta syventää projektiin osallistuvien opiskelijoiden kykyä ymmärtää erilaisuutta, asettuu toiminta menetelmällisesti lähelle freireläistä toivon pedagogiikkaa ja koko kriittisen pedagogiikan perinnettä. Teoreettisessa mielessä kyse on laajasta interventiosta, jossa pyrkimyksenä on sekä konkreettisten asiantilojen muuttaminen paremmiksi että myös osallistuvien opiskelijoiden reflektiivisyyteen ja ajattelun edistämiseen liittyvä ulottuvuus (ks. Suojanen 2014, 4). Salomäen ennakoimattomuuteen pohjaava projektisuunnittelu, joka etenee suunnittelusta havainnointiin ja toiminnan kautta taas uudelleen suunnitteluun, noudatteleekin toimintatutkimukselle ominaista spiraalimallia. Toiminta muodostuu suunnittelun, havainnoinnin, reflektion ja uudelleensuunnittelun ikiliikkeestä (esim. Kemmis \& Wilkinson 1998). Siksi hanketta voisi kehitellä jatkossa myös kriittisen toimintatutkimuksen suuntaan. Lapset elämänsä valtiaiksi -hankkeen kaltaisen kriittisen pedagogiikan kasvatustavoitteisiin linkittyvän toiminnan avulla opettajankoulutuksessa olisikin mahdollisuus vahvistaa tulevien opettajien yhteiskunnallista ymmärrystä sekä ennen kaikkea tukea heidän kasvuaan yhteiskunnan kriittisiksi pohtijoiksi ja tulkitsijoiksi sekä toimijoiksi (esim. Brookfield 2005; Fornaciari \& Männistö 2017). Tutkimusteoreettisesti autenttisten kokemusten ja kokemusten analysoinnin kautta syntyvä tutkimuksen ja aktiivisen toiminnan hybridi loisi pohjaa uudenlaiselle kriittiseen toivon pedagogiikkaan tukeutuvan tutkimuksen kulttuurille. Tässä kulttuurissa tutkijoiden ja yliopiston opettajien tehtäväksi kirjoittamisen ja julkaisemisen lisäksi muodostuisi myös osallistuminen ja yhteistoiminta (ks. Suoranta \& Ryynänen 2014). Lapset elämänsä valtiaiksi -hanke inspiroi ankkuroimaan vastaavanlaista toimintaa opettajankoulutuslaitoksiin myös siksi, että kuvaillun kaltaista kriittistä toimintatutkimusta, ainakin niiltä osin kuin se tähtää opiskelijoiden emansipoitumiseen, oman ymmärryksen laajentumiseen sekä yhteiskunnalliseen tiedostamiseen, ei ole opettajankoulutuksessa olemassa. Opettajankoulutuksessa konkreettinen interventio saattaisi lisäksi herättää kiinnostusta marginaalisessa asemassa olevaan kriittisen pedagogiikan toimintaan, tutkimukseen ja teoriaan.

\section{Lopuksi}

Kriittinen pedagogiikka kurkottaa alueille, minne emme tajua emmekä aina edes halua katsoa. Se nostaa tutkittavaksi ilmiöitä, jotka muuten saat- 
tavat jäädä huomiotta sekä kehottaa katsomaan asioita vielä terävämmin toisen ihmisen näkökulmasta. Samalla tällainen toimintatapa nostaa väistämättä tarkasteluun myös omia asenteitamme, ajatteluamme ja sen rajoituksia. Itsetutkiskelun ohella toivon pedagogiikan avulla pyritään kohti reflektoinnin tasoa, jossa pohditaan kasvatuksen, koulutuksen ja työn arvopäämääriä yhteiskunnallisesta ja maailmanlaajuisesta näkökulmasta. Näin haastetaan jokaisen opiskelijan ammatillisia tavoitteita sekä heidän käsityksiään ympäröivästä maailmasta.

Kriittinen pedagogiikka on yhteiskunnallisen kasvatustodellisuuden tarkastelutapa, joka ohjaa tutkimuskohteiden valintaa. Se ammentaa taistelutahtonsa Etelä-Amerikan luokkataisteluista, Yhdysvaltojen afroamerikkalaisten kansalaisoikeustaisteluista sekä työväenliikkeen ja feminismin perinteestä kautta läntisen maailman. Yhdistävänä pyrkimyksenä on tarttuminen yhteiskunnallisiin epäkohtiin. Lapset elämänsä valtiaiksi -hanke asettuu osaksi tätä tutkimusperinnettä ja toimintansa kautta kehottaa muitakin korkeakouluja astumaan mukavuusalueen ulkopuolelle - tiedostamaan ja tahoillaan tarttumaan ajassamme eläviin paikallisiin ja globaaleihin ongelmiin. Suomalaisen yhteiskunnan ja koulutodellisuuden muuttuessa yhä monikulttuurisemmaksi ja oppilaiden tarpeiden ja taustojen tullessa moninaisemmiksi vaaditaan opettajilta yhteiskunnallista ymmärrystä sekä erilaisuuden sietokykyä kasvavassa määrin.

Lähtökohtaisesti on kuitenkin oletettavaa, että Lapset elämänsä valtiaiksi -hankkeen kaltaisia projekteja on vaikea sulauttaa vallitsevaan opettajankoulutuksen paradigmaan, koska edelleen vallalla oleva tekninen tiedonintressi ei tunnista kontingenttia, yksilön ja ympäröivän yhteiskunnan suhdetta problematisoivaa opiskelutapaa. Lisäksi nykyinen hankeajattelu näyttää koulutuksessa tuottavan jatkuvasti vaihtuvia innovaatioita, joita harvemmin kehitetään pitkäjänteisesti. Pahimmillaan tässä katsauksessa kuvailtu opetustapa tuntuu vallitsevan järjestelmän näkökulmasta epätarkoituksenmukaiselta, sekavalta ja tehottomalta. Kaiken varmistamaan pyrkivässä kulttuurissa tilan antaminen ennakoimattomuudelle ei ole yksinkertaista. Juuri tästä syystä vallitsevan tilanteen haastaminen on tärkeää. Kriittinen pedagogiikka, edellä kuvatulla toivon painotuksella, on hyvä tapa rikastuttaa opettajaopiskelijoiden kokonaisvaltaista yhteiskunnallista ymmärrystä sekä haastaa heidän kasvatusasenteitaan. Samalla se haastaa koko opettajankoulutuksen toimintamalleja laajemmin. 


\section{LÄHTEET}

Brookfield, S. 2005. The power of critical theory for adult learning and teaching. Maidenhead: Open University Press.

Fornaciari, A. \& Harni, E. 2017. Antonio Gramscin hegemonian käsitteen relevanssi kasvatustieteelliselle tutkimukselle. Kasvatus \& Aika, 11 (2), 39-51.

Fornaciari, A. \& Männistö, P. 2017. Yhteiskuntasuhde osana luokanopettajan ammattia - Traditionaalista vai orgaanista toimijuutta? Kasvatus 48 (4), 353-368.

Freire, P. 2018. Pedagogy of the oppressed. London: Bloomsbury Publishing.

Giroux, H. A. \& McLaren, P. 2001. Kriittinen pedagogiikka. Tampere: Vastapaino.

Harni, E., Nikkola, T. \& Saari, A. 2018. Rakenteen ja kokemuksen komplementaarisuus laadullisen aineiston tulkinnassa ja analyysissa. Aikuiskasvatus, 38 (1), 30-45.

Husu, J. \& Toom, A. 2016. Opettajat ja opettajankoulutus - suuntia tulevaan. Selvitys ajankohtaisesta opettaja- ja opettajankoulutustutkimuksesta opettajankoulutuksen kehittämisohjelman laatimisen tueksi. Helsinki: Opetus- ja kulttuuriministeriö.

Jokikokko, K. 2005. Interculturally trained Finnish teachers' conceptions of diversity and intercultural competence. Intercultural Education 16 (1), 69-83.

Kiilakoski, T., Kinnunen, V. \& Djupsund, R. 2015. Miksi nuorisotyötä tehdään? Tietokirja nuorisotyön opetussuunnitelmasta. Helsinki: Humanistinen ammattikorkeakoulu ja Nuorisotutkimusseura/Nuorisotutkimusverkosto. Saatavissa http://www.theseus.fi/ bitstream/handle/10024/106142/978-952-456-203-4.pdf?sequence=1\&isAllowed=y (haettu 21.3. 2018).

Kemmis, S. \& Wilkinson, M. 1998. Participatory action research and the study of practice. Teoksessa Action research in practice: Partnerships for social justice in education. London: Routledge, 21-36.

Lapping, C. 2011. Psychoanalysis in social research. Shifting theories and reframing concepts. London and New York: Routledge.

Lindén, J. 2010. Kutsumuksesta palkkatyöhön? Perusasteen opettajan työn muuttunut luonne ja logiikka. Väitöskirja. Acta Universitatis Tamperensis 1502. Tampere: Tampere University Press.

Löfström, J., Virta, A. \& Salo, U. 2017. Valppaaksi kansalaiseksi - Yhteiskuntatiedollisen opetuksen taito ja teoria. Historiallis-yhteiskuntatiedollisen kehittämiskeskuksen tutkimuksia 15. Helsinki: Historiallis-yhteiskuntatiedollinen kehittämiskeskus.

Männistö, P., Fornaciari, A. \& Tervasmäki, T. 2017. Perusopetuksen opetussuunnitelmien (1985-2014) osallisuuskäsityksen sosiaalipedagoginen tarkastelu. Teoksessa A. Toom, M. Rautiainen \& J. Tähtinen (toim.). Toiveet ja todellisuus. Kasvatus osallisuutta ja oppimista rakentamassa. Kasvatusalan tutkimuksia 75. Jyväskylä: Suomen kasvatustieteellinen seura, 89-111.

Nikkola, T., Rautiainen, M. \& Räihä, P. 2013. Toinen tapa käydä koulua. Kokemuksen, kielen ja tiedon suhde oppimisessa. Tampere: Vastapaino. 
POPS 2014. Perusopetuksen opetussuunnitelman perusteet. Helsinki: Opetushallitus.

Rautiainen, M., Vanhanen-Nuutinen, L. \& Virta, A. 2014. Demokratia ja ihmisoikeudet: tavoitteet ja sisällöt opettajankoulutuksessa. Helsinki: Opetus-ja kulttuuriministeriö.

Räihä, P. 2010. Koskaan et muuttua saa - luokanopettajakoulutuksen opiskelijavalintojen uudistamisen vaikeudesta. Akateeminen väitöskirja. Tampere: Tampereen yliopisto.

Räisänen, M. 2014. Opettajat ja koulutuspolitiikka. Opetusalan ammattijärjestö ja Demokraattiset koulutyöntekijät-yhdistys peruskoulukauden koulutuspolitiikassa. Akateeminen väitöskirja. Tampere: Tampereen yliopisto.

Salminen, S. \& Säntti, J. 2013. Akateemisesta varjosta kansainvälistyvän tieteen valokeilaan: luokanopettajakoulutuksen kehitys 1960-luvulta 2010-luvulle Helsingin väliaikaisessa opettajakorkeakoulussa ja Helsingin yliopistossa. Teoksessa J. Rantala \& M. Rautiainen (toim.) Salonkikelpoiseksi maisterikoulutukseksi - luokanopettajaja opinto-ohjaajakoulutuksen akatemisoitumiskehitys 1970-luvulta 2010-luvulle. Turku: Suomen kasvatustieteellinen seura, 106-128.

Salomäki, T. 2010. Projektista prosessiin Virossa ja Venäjällä. Teoksessa L. Viinamäki (toim.) Sosionomikoulutus (AMK \& ylempi AMK) kansainvälistyvillä koulutus- ja työmarkkinoilla. Kemi: Kemi-Tornion ammattikorkeakoulun julkaisuja, Sarja A: Raportteja ja tutkimuksia 2/2010, 115-127.

Simola, H., Kauko, J., Varjo, J., Kalalahti, M. \& Sahlström, F. 2017. Dynamics in education politics: understanding and explaining the Finnish case. London: Routledge.

Sitomaniemi-San, J. 2015. Fabricating the Teacher as Researcher: A Genealogy of Research-Based Teacher Education in Finland. Tampere: Juvenes.

Suojanen, U. 2014. Toimintatutkimus ammatillisen kehittymisen välineenä. Saatavissa https://metodix.fi/2014/05/19/suojanen-toimintatutkimus (haettu 20.2.2018).

Suoranta, J. \& Ryynänen, S. 2014. Taisteleva tutkimus. Helsinki: Into.

Syrjäläinen, E., Eronen, A. \& Värri, V-M. 2006. Opettajaksi opiskelevien kertomaa. Opettajaksi opiskelevien yhteiskunnallinen asennoituminen ja käsityksiä omista vaikuttamismahdollisuuksistaan yliopistossa. Helsinki: Historiallisyhteiskuntatiedollisen kasvatuksen tutkimus-ja kehittämiskeskuksen tutkimuksia 6.

Säntti, J. 2007. Pellon pientareelta akateemisiin sfääreihin. Opettajuuden rakentuminen ja muuttuminen sotienjälkeisessä Suomessa opettajien omaelämäkertojen valossa. Helsinki: Helsingin yliopisto ja Suomen kasvatustieteellinen seura, kasvatusalan tutkimuksia 31 .

Vuorikoski, M. \& Räisänen, M. 2010. Opettajan identiteetti ja identiteettipolitiikat hallintakulttuurien murroksissa. Kasvatus \& Aika 4 (4), 63-81.

Värri, V-M. 2004. Opettajankoulutus kasvatuksen, katsomuksen ja vastakulttuurin ohjelmana. Tiedepolitiikka 29 (2), 22-28. 
94 - Sosiaalipedagoginen aikakauskirja, vuosikirja 2018, vol. 19 